\title{
Using Capture Theory and Chronology in Eminent Domain Proceedings
}

\author{
John Ryskamp
}

Until meaningful changes in eminent domain law give property owners a better chance to fight eminent domain proceedings, the old minimum scrutiny for eminent domain-reaffirmed in Kelo v. New London - remains. That standard allows eminent domain use if the use is rationally related to a legitimate government purpose. That sounds as though virtually anything would qualify. Is there anything concrete in it which would give property owners a way to fight back? There is. It is the phrase "government purpose."

Prior to Kelo, the Supreme Court had said that the government purpose need only be "conceivable"2-apparently something the Court could conclude retrospectively. This raised the question, whether there need in fact be a government purpose? The Court answered this, prior to Kelo, in Virginia v. United States. In Virginia, the Court found that there must be a very high level of proof to justify gender discrimination in public education. In discussing government purpose, the Court said that the government purpose "must be genuine, not hypothesized or invented post hoc in response to litigation."3 There must in fact be a government purpose, and it is concluded prospectively, not retropectively.

In his Kelo concurring opinion, Justice Kennedy articulated the factual criteria for government purpose by laying out a whole program of civil discovery for litigants to follow. In it, he synthesized, under the concept of "primary," the twin aspects of government purpose, factual and prospective. Private parties are evaluated by the place they hold in the chronology, not the role they play in the development. That is, the goal of discovery is establish the chronology, because the distinction between public purpose and private purpose turns on the chronology. He wrote: "A court confronted with a plausible accusation of impermissible favoritism to private parties should [conduct]....a careful and extensive inquiry into "whether, in fact, the development plan [chronology]

[1.] is of primary benefit to ... the developer..., and private businesses which may eventually locate in the plan area...,

[2.] and in that regard, only of incidental benefit to the city....[,]"

and whether the chronology shows

“[3.] awareness of...depressed economic condition and evidence corroborating the validity of this concern...,

${ }^{1} 545$ US (2005).

${ }^{2}$ Hawaii Housing Authority v. Midkiff, 467 US 229, 241 (1984).

${ }^{3}$ United States v. Virginia, 518 US 515, 533 (1996). 
[4.] the substantial commitment of public funds...before most of the private beneficiaries were known...,

[5.] evidence that [government] reviewed a variety of development plans...[,]

[6.] [government] chose a private developer from a group of applicants rather than picking out a particular transferee beforehand and...

[7.] other private beneficiaries of the project [were]... unknown [to government] because the...space proposed to be built [had] not yet been rented...."

These are all prospective criteria; government purpose is shown ab initio, not post hoc. And it is shown by facts. Nor is the "primary" test limited, with respect to discovery, as to the earliest date of relevance. For example, "primary" with respect to "awareness," does not imply a particular starting date; government has the burden of showing what facts make up its "awareness." These are all criteria subject to depositions, document subpoenas, and the usual orders and procedures of civil discovery. Kennedy added: "The trial court concluded, based on these findings, that benefiting Pfizer [a drug company interested in locating facilities on the land seized by eminent domain] was not 'the primary motivation or effect of [New London's] development plan'; instead, 'the primary motivation for [New London] was to take advantage of Pfizer's presence'....Likewise, the trial court concluded that ' $[\mathrm{t}]$ here is nothing in the record to indicate that...[New London was] motivated by a desire to aid [other] particular private entities.... ${ }^{4}$ Kennedy makes it clear that government purpose is an issue of fact for the trier of fact.

The factual distinction between public and private purpose is well known in political science, as capture theory, in which private purpose with respect to certain facts, is substituted for government purpose with respect to those facts. Purpose as fact, is not at all the issue. What the Court wants to know is, whose purpose? And it wants a factual showing on that issue. ${ }^{5}$ It is highly ironic, therefore, that in the true facts of Kelo-which came out after the Court decided the case-it was learned that New London had had a private purpose after all. The true chronology didn't meet a single one of Justice Kennedy's criteria. New London had simply lied to the Court. New London had argued the following chronology to the Supreme Court:

1. New London decided, based on a factual inquiry, that it wanted to revitalize;

\footnotetext{
${ }^{4}$ Kelo, slip. op. (Kennedy, J., concurring) at 2-3 (citations omitted).

${ }^{5}$ See Peter Kulick, "Rolling the Dice: Determining Public Use in Order to Effectuate a 'Public-Private' Taking-A Proposal to Redefine 'Public Use," http: //ssrn.com/abstract=262585; Jim Rossi, "Moving Public Law Out of the Deference Trap in Regulated Industries," http://ssrn.com/abstract=657202; Joel S. Hellman et al., "Seize the State, Seize the Day: State Capture, Corruption and Influence in Transition," http://ssrn.com/abstract=240555; Irina Slinko et al., "Laws for Sale: An Empirical Study of the Effects of Regulatory Capture," http://ssrn.com/abstract=402840. For a larger context, see Michael W. Klein, "Risk, Taxpayers, and the Role of Government in Project Finance," http://ssrn.com/abstract=620626; John T. Cuddington, "Analyzing the Sustainability of Fiscal Deficits in Developing Countries," http://ssrn.com/abstract=597231. The "capture" phenomenon is also well-known under the name "iron triangle," the substituting of private for public purpose involving three actors: legislators, bureaucrats and constituencies. See Francis E. Rourke, Bureaucracy, Politics, and Public Policy (Harpercollins 1984).
} 
2. New London announced its desire;

3. Pfizer Corporation heard about it and approached New London with a plan.

\section{New London accepted Pfizer's plan.}

That was not, in fact, what had happened:

In mid-July [2004, after the Supreme Court had decided to hear the Kelo case, which it decided in June of 2005], as commentators and politicians around the country decried [New London's] attempt to seize private homes for economic development on the Fort Trumbull peninsula, a press release appeared on the Web site of Pfizer Inc. The pharmaceutical company, whose \$300 million research complex sits adjacent to what remains of the neighborhood, announced that it wanted to set the record straight on its involvement in the Fort Trumbull development project. The project, the statement said, wasn't Pfizer's idea. "We at Pfizer have been dismayed to see false and misleading claims appear in the media that suggest Pfizer is somehow involved in this matter," the statement said. The writers said the company "has no requirements nor interest in the development of the land that is the subject of the case." But a recent, months-long review of state records and correspondence from 1997 and 1998-when officials from the administration of then-Gov. John G. Rowland were helping convince the pharmaceutical giant to build in New London-shows that statement is misleading, at best. In fact, the company has been intimately involved in the project since its inception, consulting with state and city officials about the plans for the peninsula and helping to shape the vision of how the faded neighborhood might eventually be transformed into a complex of high-end housing and office space, anchored by a luxury hotel. The records—obtained by The Day through the state Freedom of Information Act—show that, at least as early as the fall of 1997, Pfizer executives and state economic development officials were discussing the company's plans, not just for a new research facility but for the surrounding neighborhood as well. And, after several requests, the state Department of Economic and Community Development [DECD] produced a document that both the state and Pfizer had at first said did not exist: a 1997 sketch, prepared by CUH2A, Pfizer's design firm for its new facility. Labeled as a "vision statement," it suggested various ways the existing neighborhood and nearby vacant Navy facility could be replaced with a "high end residential district," offices and retail businesses, expanded parking and a marina. Those interactions took place months before Pfizer announced that it would build in the city, on the site of the former New London Mills linoleum factory, and months before the New London Development Corp. announced its redevelopment plans for the neighborhood and the former Naval Undersea Warfare Center next door. The NLDC's plans, while different in many respects from the hand-drawn 1997 plan, maintain the vision statement's core purpose - a total replacement of the existing stock of modest homes, apartment houses and businesses, and the development of upscale housing and office space to jibe with the new Pfizer complex. NLDC and city officials have long characterized their efforts to recast the working-class neighborhood as a response to Pfizer's decision to build on the peninsula, rather than a move made as a condition of Pfizer's involvement in the project. And in the state and federal court rulings that upheld the city's takings of homes for the private development project, judges at every level of the judiciary have assumed the same. Even in a blistering dissent, which warned that the NLDC's plan left all private property under the "specter of condemnation," U.S. Supreme Court Justice Sandra Day O'Connor sets the beginning of the case in February 1998, when Pfizer announced its plans to build its facility. While challenging the constitutionality of the eminent domain project, O'Connor and the other justices accept that it was an independent effort to "complement" the construction of a research complex next door. But in a series of recent interviews, several former high-ranking state officials confirmed what 
opponents of the project have long insisted and what the company continues to deny: the state's agreement to replace the existing neighborhood was a condition of Pfizer's move here....Any attempt to clarify the origins of the development project is hindered both by the passage of time and by the fact that many of the participants in the earliest discussions with the company will not, or cannot talk about their efforts. Peter N. Ellef, who as DECD commissioner and later [former Governor] Rowland's co-chief of staff oversaw the state's involvement, is awaiting trial on federal corruption charges stemming from his years in the governor's office....Rowland, who publicly embraced this and other urban development projects and poured in state bond funds, sits in federal prison in Pennsylvania after pleading guilty to a corruption charge....But some former members of the Rowland administration with knowledge of the state's negotiations with Pfizer, speaking on the condition of anonymity because they wished to spare their relationships with current and former colleagues, confirmed Pfizer's involvement in the planning of the Fort Trumbull project. The company's formal assistance agreements with the state, which lay out more than $\$ 118$ million in financial incentives and other amenities that were offered by the state and the city to convince Pfizer to build in New London, does not specifically offer to redevelop the neighborhood. But the redevelopment project, largely paid for with an additional $\$ 73$ million in bonded funds, was an integral part of the state's deal with Pfizer, the officials said, and the company would not have built its headquarters in New London without being assured that the surroundings would undergo a radical change. "They would not have done the deal without the commitment to make the surrounding area more livable," said a high-ranking official who was privy to negotiations between Pfizer and the state. "They were trying to attract people with Ph.D.s who make $\$ 150,000$ to $\$ 200,000$ a year to eastern Connecticut... and they were not going to tell them they had to drive to work through a blighted community....I'm not going to tell you it was a difficult decision," the official said. "It wasn't, because of the number of jobs...."But for years, executives at Pfizer, along with the state and the NLDC, have disputed that view. Instead, they have maintained that the effort to redevelop the neighborhood came only in response to Pfizer's announcement that it would locate its headquarters here, and they have insisted that the company never directed the state or city to overhaul the surrounding area in exchange for that construction....In interviews, however, the state officials made clear that the difference between a demand by Pfizer and a statement of preference about what it would like to see next door was a small one, especially when the city and state had already committed to invest, according to figures from the DECD, a total of $\$ 118$ million in other incentives. "This wasn't like convincing a bank in Norwalk to move to Stamford," a former NLDC employee said. "This was a major league deal. This was 2,000 jobs, et cetera. They know what that means. DECD knows what that means.... What do we need to make this happen?"....In retrospect, the company's interest in the Fort Trumbull project does not seem to have been much of a secret at the state level, where the project seems largely to have been treated as part of the package of incentives prepared for Pfizer. For instance, on Dec. 11, 1997, DECD Commissioner James F. Abromaitis wrote...[that the state would help] by "defraying the cost of that development and improving its value through a comprehensive, state-funded waterfront improvement and development project," seemingly a reference to the Fort Trumbull neighborhood....In the meantime, the NLDC and the city-not the state, and not Pfizer-have absorbed the sharpest criticism since the Supreme Court decision brought the New London case to the public eye. And that, one of the state officials said, was no accident. "They have taken all the missile attacks," the official said, referring to the development corporation. "That's the beauty of distance.",

Thus, the true chronology was

\footnotetext{
${ }^{6}$ The Day, October 16, 2005 (New London, Connecticut, archived at www.theday.com).
} 
1. New London wanted Pfizer to locate in New London;

2. Pfizer approached New London with its plan;

3. New London adopted the plan;

4. New London announced its redevelopment plan.

What is missing in the second chronology? What is missing is the government purpose. There is only Pfizer's purpose. Private purpose has been substituted for government purpose, and so the development plan fails (should have failed) minimum scrutiny.

Now that the scam has been revealed in the famous Kelo case, litigants are turning to the government purpose prong of minimum scrutiny, in order to save their property. One lawsuit in New Jersey directly invokes Justice Kennedy's criteria: “In his Kelo concurrence, Justice Kennedy commented that the evidence showed that New London, 'reviewed a variety of development plans and chose a private developer from a group of applicants rather than picking out a particular transferee beforehand.' Plaintiffs contend that did not happen here. Long Branch [New Jersey city government] promised the area to the [private development business] principals before the [private development business] was even created, and then everything - the designation of the area in need of redevelopment, the creation of [the private development business], the designation of [the private development business] as the developer, the passing of the Ordinance authorizing eminent domain-all were implemented to seal the deal." Indeed, this action reaches back into the actions of the principals, pointing out their acquisition of properties and running them down purposely, in order to provide the government finding of "blight" which was legally necessary to proclaim a plan for redevelopment and the invoking of the eminent domain power. ${ }^{7}$

The Kelo Court accepted that private purpose can play a role in eminent domain use, finding that " $[\mathrm{t}]$ here is, moreover, no principled way of distinguishing economic development from the other public purposes that we have recognized." 8 However, that camouflaged the proper distinction to be made, between government and private purpose, for which there is a principled way to distinguish. The true facts in Kelo also shed light on another criteria which Justice Kennedy did not mention: deception. Does government lie about the chronology? If it did, that undermines its credibility when it comes to all the other criteria, since all the other establish chronology.

Finally, lying about the chronology undermines another prong of minimum scrutiny which government might claim it meets in its attempt to use eminent domain: rational. There is nothing rational about the lie. This, in turn, sheds light on the third prong: relates. That is also a question of fact for the trier of fact. What government does is not assumed to be rational: that is something government must prove. "Relates" means interrelates. Government must show that its chronology is internally consistent. New London understood the legal test for government purpose perfectly well. It understood perfectly well that each prong of minimum scrutiny - rational, relate, government-is a question of fact for the trier of fact. It knew it had to conceal what it had done, or the

\footnotetext{
${ }^{7}$ Complaint at 6 . This complaint is online at www.kevinbrownformayor.com.

${ }^{8}$ Kelo, slip op., at 14.
} 
Court would not have allowed it to use eminent domain. Discovery may also reveal that the developers also understand that the government purpose test is a factual test, and that they need to help government to show that there was no substitution of private purpose for public purpose. This raises the possibility of civil conspiracy charges as well as lawsuits brought under the Racketeering and Corrupt Organizations Act (RICO). So documents are shredded, people are transferred, memories fail. In these cases, revealing the chronology is exactly what must be done to stop eminent domain uses if there is no law which will stop them, and given the idiotically vague 'reforms' which have been proposed, litigation will more and more turn on establishing the facts with respect to the government purpose test. Chronology will turn out to be hugely important in these cases. If the true chronology in New London had been known-instead of the lying chronology presented by New London-Susette Kelo would have won her case. Enough said. 